INTERNATIONAL JOURNAL OF ENGINEERING, SCIENCE AND TECHNOLOGY

www.ijest1-ng.com www.ajol.info/index.php/ijest

(C) 2021 MultiCraft Limited. All Rights Reserved

\title{
Physicochemical characterization of biochars from Eucalyptus maiden Entandrophragma cylindricum (Liboyo), Milicia excelsa (Muvula.) and Ocotea michelsonie (licheche) used in Goma city, DR Congo for water treatment potentials
}

\author{
Amboko Benjamin Muhiwa ${ }^{1}$, Mathias Fru Fonteh ${ }^{2,3}$, Estella Buleng Tamungang Njoyim ${ }^{4,5}$, François \\ N. Gapgue ${ }^{6}$ \\ ${ }^{I}$ Faculty of Applied Sciences and Technologies of Great Lakes Free University of Goma, DEMOCRATIC REPUBLIC OF THE CONGO \\ ${ }^{2}$ Department of Rural Engineering, Faculty of Agronomy and Agricultural Sciences, University of Dschang, CAMEROUN \\ ${ }^{3}$ College of Technology, The University of Bamenda, CAMEROUN \\ ${ }^{4}$ Department of Chemistry, Faculty of Science, University of Dschang, CAMEROUN \\ ${ }^{5}$ Department of Chemistry, Higher Teacher Training College, The University of Bamenda, CAMEROUN \\ ${ }^{6}$ Department of Civil Engineering, Fotso Victor University, Institute of Technology, University of Dschang, CAMEROUN \\ E-mail: E.B.T. Njoyim ${ }^{4,5}$ (bulengyim@yahoo.com, Corresponding Author) \\ ORCID iDs: https://orcid.org/0000-0003-0153-4816 (Muhiwa), https://orcid.org/0000-0001-6099-7656 (Fonteh), https://orcid.org/0000-0002-3874-473X
} (Njoyim), https://orcid.org/0000-0002-5098-8243 (Gapgue)

\begin{abstract}
In recent years, research on biochar as an eco-friendly material and cost-effective means for water treatment, soil amendment and carbon sequestration has gained more attention due to the availability of feedstock, the simplicity of the preparation methods, and their enhanced physico-chemical properties. Given that pyrolysis temperature and resident time amongst other factors have significant effect on biochar's pollutant removal efficacy, this study focused on the evaluation of some properties of biochars produced by pyrolysis $\left(500-600{ }^{\circ} \mathrm{C}\right)$ from Entandrophragma cylindricum (ECB), Eucalyptus maiden (EMB), Milicia excelsa (MEB) and Ocotea michelsonie (OMB) sawdusts for their water treatment potentials by using standardized methods. Biomass generated from wood mill in the city of Goma (DR Congo) is valorised for the first time as potential water purifier. The highest yield was obtained from OMB (36.6\%) which was found to be significantly greater that those of ECB and EMB $(\mathrm{p}<0.05)$. All the biochars had neutral to weakly alkaline $\mathrm{pH}(7.10-7.90)$, very high porosity $(92-94 \%$, with EMB having the highest value) and ash content between 9.40 and $18.40 \%$, with the highest value attributed to OMB). Most physical and chemical characteristics of biochars varied significantly due to different wood species. Potential toxic elements were far below environmental threshold values and exchangeable cations were equally detected in the biochars. The obtained biochars are therefore seen as good media for water treatment.
\end{abstract}

Keywords: Water treatment, pyrolysis, removal efficacy, ash content, contaminants, porosity

DOI: http://dx.doi.org/10.4314/ijest.v13i2.2

Cite this article as:

Muhiwa A.B., Fonteh M.F., Njoyim E.B.T., Gapgue F.N. 2021. Physicochemical characterization of biochars from Eucalyptus maiden Entandrophragma cylindricum (Liboyo), Milicia excelsa (Muvula.) and Ocotea michelsonie (licheche) used in Goma city, DR Congo for water treatment potentials. International Journal of Engineering, Science and Technology, Vol. 13, No. 2, pp. 15-24. doi: 10.4314/ijest.v13i2.2 


\section{Introduction}

Water quality is continuously deteriorating due to rapid industrialization, population expansion and climate change (Lumnwi et al., 2018). The resulting pollution caused by chemicals and/or pathogenic microorganisms poses a serious threat to the well-being of the earth and its people. According to (UNICEF and WHO, 2015; Biosengazeh et al., 2020, 663 million people with 319 million in Sub-Saharan Africa, of which $80 \%$ live in rural areas, still lack improved drinking water sources. These figures show the failure of the United Nations millennium Development Goals (MDGs) in Sub-Saharan African countries. Recently, with the adoption of Sustainable Development Goals (SDGs), the United Nations through SDG 6 intend to ensure the availability and sustainable management of water and sanitation for the entire world population by 2030 (UN, 2015, Nchofua et al., 2020). However, SDG 6 may only be achieved in Sub-Saharan African countries if community-based water treatment methods are elaborated and practically put in use. In this regard, biochar technology appears to be promising as it relies on locally readily available materials and uses local skills, making it appropriate for small and low-income communities (Niwagaba et al., 2014).

The origin of biochar is traced to the ancient populations of Indian America in the Amazon region, known locally as "Terra Preta de Indio", where black earth was created using coal, traditionally produced (Lehmann, 2009). Research on Terra Preta soils (anthroposols) in the Amazon revealed the effects of biochar on soil by the improvement of its fertility in a sustainable way. Biochar is defined as char produced by pyrolysis for use in agriculture (and other non-thermal applications) in an environmentally sustainable manner (EBC, 2013). As a stable carbon-rich material Biochar shows incredible potential to handle water/wastewater contaminants (Enaime et al., 2020). It is generally produced by pyrolysis from agricultural residues, manure or wood, and characterised by having a large surface area $\left(200-1000 \mathrm{~m}^{2} / \mathrm{g}\right)$, low density and high porosity which makes it an efficient adsorbent and good biofilm carrier (Downie et al., 2009; Enaime et al., 2020). Due to its unique properties, there is growing interest in using it as a filter medium to enhance water and wastewater quality (Perez-Mercado et al., 2018). Many studies have also demonstrated its efficiency as an adsorbent and biofilm carrier for removing organic matter, surfactants, phosphorus (P) and nitrogen $(\mathrm{N})$ from onsite wastewater and greywater treatment systems (Rasheed et al., 2017; Gwenzi, 2018; Ye et al., 2019). However, its physical, chemical and structural properties can vary greatly depending on the type of organic material used and the biochar production conditions (temperature, heating rate and oxidation) (Perez-Mercado et al., 2018).

The Democratic Republic of Congo (DRC) has one of the highest available water resources in Africa. However, potable water supply remains a major concern in many urban and rural communities in this country. The DRC is one of the Sub-Saharan African countries which have recorded the highest number of cases of cholera. In 2017, 55000 people fell sick that is $28 \%$ more compared to the previous year and 1190 died in 24 of the 26 provinces of the country (RDC, 2018). The country is also very rich in forestry species which are generally used for wood works generating by-products such as sawdust that causes serious environmental problems as they are not managed in a suitable way. Some authors in DRC have worked on biochar as part of soil amendment (Peltier et al., 2010; Lele, 2016; Schure et al., 2019). However, no critical work has focused on the potential use of wood biochar for water purification in this country.

The main objective of the study was to assess the potential of wood species in Goma for water treatment as a contribution to enhancing the access to portable water of the population.

Specifically, the study focused on the:

- Determination of wood species widely used in Goma from which biochar can be obtain

- Determination of the biochar yield of the identified wood species.

- Evaluation of the biochars physicochemical characteristics for their potentials in the purification of water.

This research focuses on the valorisation of biomass generated from wood mill in the city of Goma which may serve as potential water purifier thus, mitigating environmental pollution as well as providing sustainable water supply to households in the city in particular and the entire DRC in general.

\section{Identification of wood species widely used in the city of Goma}

A questionnaire was administered to eight sawmills in the city to identify the most used lumber in the city. Two selection criteria (quality and the availability of species) guided the investigation. The non-parametric test was applied to identify the most commonly used wood species and the species that produces the highest quantity of sawdust.

\section{Biochar production and determination of biochar yield}

Variation in pyrolytic temperatures and feedstocks affects the yield and nutrient composition of biochar (Naeem et al., 2014). During pyrolysis, biomass undergoes a variety of physical, chemical and molecular changes. Volatilization during pyrolysis causes significant loss in mass and therefore volume reduction and shrinking without causing much change to the original structure of the feedstock (Laine et al., 1991). In addition, pyrolysis affects cation exchange capacity (CEC), pH and carbon content of biochar (Wu et al., 2012; Naeem et al., 2014). Yield determination is thus of prime importance to determining optimum condition and the best feedstock for the production of biochar for a particular use. The raw materials were collected in bags and transported to the biochar production site. Pyrolysis was carried out in a traditional Adam Retolt Kiln oven. Pyrolysis temperatures were taken every 
20 minutes using a chromel alumel thermocouple until completion. Each sample was pyrolyzed in ten cycles and the masses were taken before and at the end of each production, using a salsa balance and the production yields calculated by using formula 1 (Naeem et al., 2014; Boris et al., 2018).

$$
B_{y}(\%)=\left(\frac{R_{W}}{B_{W}}\right) \times 100
$$

where $\mathrm{B}_{\mathrm{y}}=$ yield of biochar (\% on a mass basis), $\mathrm{R}_{\mathrm{w}}=$ weight of raw dry material $(\mathrm{kg})$, and $\mathrm{B}_{\mathrm{w}}=$ weight of biochar $(\mathrm{kg})$.

\section{Physical characterization of biochars}

Three samples from a mixture of 10 pyrolyses of each type of biochar were analysed.

\subsection{Particle size analysis}

The shape and size of external biochar pores is a function of particle size and particle morphology (Lim et al., 2017). Particle size and particle morphology are often expressed in terms of Uniformity Coefficient (UC) and have a significant impact on biochar's ability to retain or eliminate contaminant from water. The particle size analysis was carried out following method prescribed by NF P 94-054 (1991). The process consisted of weighing $200 \mathrm{~g}$ of the sample, sieving it on a Controlab brand electronic sieve with a battery of sieves ranging from 0.2 to $10 \mathrm{~mm}$ for 10 minutes and weighing the residue from each sieve. The uniformity coefficient (UC) was determined by formula 2 :

$$
\text { U.C }=\left(\frac{D_{60}}{D_{10}}\right) \times 100
$$

where

$$
\mathrm{D}_{60}=\text { size (in mm) of screen opening where } 60 \% \text { of a sample passes and } 40 \% \text { is retained }
$$

$\mathrm{D}_{10}=$ size (in $\mathrm{mm}$ ) of screen opening where $10 \%$ of a sample passes and $90 \%$ is retained.

\subsection{Biochar porosity}

The biochar porosity ( $\Phi$ ) was determined using bulk and particle densities using formula 3 (Boris et al., 2018).

$$
\Phi=1-\left(\frac{\rho_{a}}{\rho_{s}}\right)
$$

where $\rho_{a}=$ bulk density $\left(\mathrm{g} / \mathrm{cm}^{3}\right)$, and $\rho_{s}=$ particle density $\left(\mathrm{g} / \mathrm{cm}^{3}\right)$.

\subsection{Bulk and particle densities}

Density and porosity are fundamental physical properties that control how biochar interacts with water. The bulk density $\left(\rho_{a}\right)$ was determined according to NF X 31-503 (1992) by dividing the difference between the mass of the crucible filled with the sample and the mass of empty crucible with the crucible's volume. Particle density $\left(\rho_{s}\right)$ was determined according to NF P 94054 (1991). The principle was to measure the volume of grains excluding voids and to calculate the ratio between their weight and their volume.

\subsection{Water content}

The water content was determined by the gravimetric method at $105{ }^{\circ} \mathrm{C}$ (Pauwels et al., 1992). Five grams of wet sample in a crucible and heated in a Carbolite Eurotherm furnace at $105^{\circ} \mathrm{C}$ for 5 hours. After cooling, water content was calculated using formula 4.

$$
W \%=\left(\frac{m_{w}-m_{d}}{m_{d}}\right) \times 100
$$

where $\mathrm{m}_{\mathrm{w}}=$ mass of the wet sample in grams $(\mathrm{g})$ and $\mathrm{m}_{\mathrm{d}}=$ mass of dry sample in grams $(\mathrm{g})$.

\section{Chemical characterization of biochars}

\subsection{Determination of ash content, electrical conductivity and $\mathrm{pH}\left(\mathrm{H}_{2} \mathrm{O}\right)$}


Ash refers to the inorganic residue remaining after either ignition or complete oxidation of organic matter in biomass. The ash content is a measure of the mineral content and other inorganic matter in biomass (National Renewable Energy Laboratory, 2008). Biochar's ash content can play a positive or negative role for the removal of heavy metals in water depending on its dominant ions (cations or anions). Ash content was determined using the dry incineration method (Pauwels et al., 1992). Five grams of sample were placed in a crucible and heated in a Carbolite Eurotherm furnace at $450^{\circ} \mathrm{C}$ for 5 hours. After cooling, the dried sample was weighed. The ash content was calculated using formula 5:

$$
\% \text { Ash }=\frac{m_{1}-m_{2}}{m} \times 100
$$

where $\mathrm{m}_{1}=$ mass $(\mathrm{g})$ after incineration (sample + crucible), $\mathrm{m}_{2}=$ mass $(\mathrm{g})$ of the crucible and $\mathrm{m}=$ the original mass $(\mathrm{g})$ of the sample.

The electrical conductivity and the $\mathrm{pH}\left(\mathrm{H}_{2} \mathrm{O}\right)$ were determined by the method described by Rajkovich et al. (2011).

\subsection{Determination of total nitrogen}

Total nitrogen content was determined according to the Kjeldahl method (Bremner, 1965). Organic nitrogen was completely mineralized with a mixture of concentrated sulfuric acid and hot salicylic acid. The mixture was distilled off and the ammonia generated was trapped by a solution of boric acid and later on titrated with a solution of sulfuric acid $(0.01 \mathrm{~N})$.

\subsection{Organic Carbon (\%)}

Organic Carbon (\%) was determined as described by Rodier et al. (2009). The organic carbon of biochar was oxidized by a solution of excess potassium dichromate $\left(\mathrm{K}_{2} \mathrm{Cr}_{2} \mathrm{O}_{7}\right)$, in a sulfuric acid medium. The excess potassium dichromate not reduced by organic carbon was then titrated with a solution of ferrous sulphate $\left(\mathrm{FeSO}_{4} .7 \mathrm{H}_{2} \mathrm{O}\right)$ in the presence of diphenylamine which turns from purple to green at the equivalence point. Total carbon was determined by the sum of organic carbon and graphitic carbon. Nitrate was determined according to the Kjeldahl method (Bremner, 1965) by mixing $25 \mathrm{~mL}$ of sample with devada alloy followed by distillation and lastly titration with $0.01 \mathrm{~N} \mathrm{H}_{2} \mathrm{SO}_{4}$ solution. The nitrite content was then determined from nitrate by using formula 6.

$$
\left[\mathrm{NO}_{2}^{-}\right]=0.742 \times\left[\mathrm{NO}_{3}^{-}\right]
$$

\subsection{Determination of chloride and phosphorus contents}

Chloride content was determined by argentometric titration with silver nitrate in the presence of potassium chromate as an indicator as described by CEAEQ (2015) after extracting the sample with distilled water. The extraction of phosphorus was analogously to that described for chloride above. The determination of phosphorus in the filtrate was done by molecular absorption spectrophotometric method as described by Rodier et al. (2009).

\subsection{Determination of metals}

Calcium, Magnesium, Potassium, Sodium, Manganese, Lead, Iron, Copper, Aluminum and Zinc were determined by flame atomic absorption spectrophotometry using the brand Perkin-Elmer device, after mineralization of samples in the oven and their solubilization with acid. The samples were crushed and $10 \mathrm{~g}$ to $1 / 10 \mathrm{mg}$ each was weighed and placed in an oven at $450{ }^{\circ} \mathrm{C}$ followed by dissolution in hydrochloric acid $(0.05 \mathrm{~N} \mathrm{HCl})$ and filtration of the solution. Calibration curves were then plotted with a range of different known concentrations for each metal. The wave length of each element was read and its concentration was calculated.

\section{Statistical analysis}

GenStat software was used for statistical analysis which consisted of comparing the means by analysis of variance (ANOVA). In cases of significant differences, the means were separated using the Smallest Significant Difference. The significance level for all analysis was $1 \%$.

\section{Results and discussion}

\subsection{Identification of wood species}

Following the survey results, four species were selected: Eucalyptus maideni, Milicia excelsa, Entandrophragma cylindricum and Ocotea michelsonie. These were the four species commonly used (Figure 1). Thus, generating the highest quantities of sawdust in all the sawmills visited. From Figure 1, all the sawmills (100\%) use the above-mentioned species and only 25, 15, 14 and $13 \%$ of them use other woods such as Julbernardia Sarreti, Strombosia Schefflera, Abizia Girmmifera and Alstonia Boonni 
respectively. The choice for the high use of Eucalyptus maideni, Milicia excelsa, Entandrophragma cylindricum and Ocotea michelsonie was related to their high abundance and the high quality of timber resulting from these woods as testified by users.

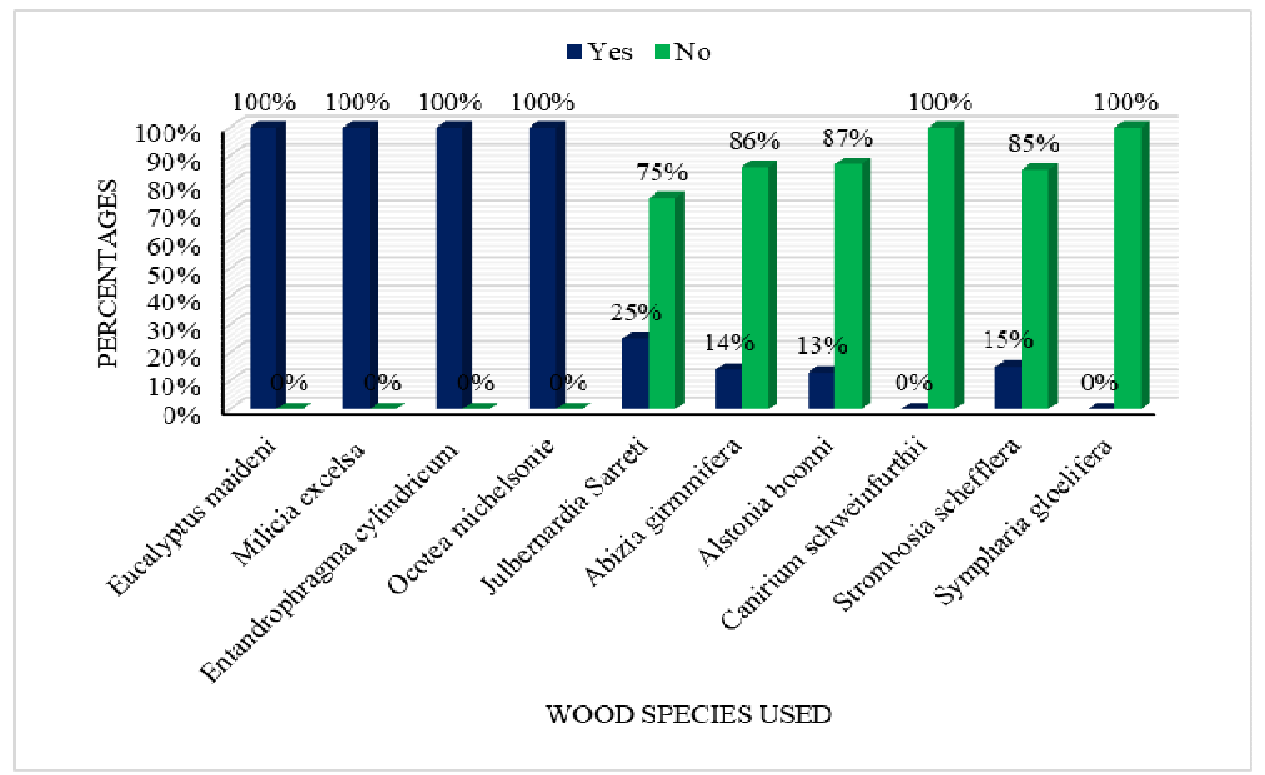

Figure 1: Percentages of wood species commonly used in Goma

\subsection{Biochar production and yield}

The parameters related to the production of biochar are summarized in Table 1

Table 1. Parameters related to biochar production

\begin{tabular}{|l|l|l|l|l|l|}
\hline & Unit & $\begin{array}{l}\text { Eucalyptus } \\
\text { maideni }\end{array}$ & $\begin{array}{l}\text { Milicia } \\
\text { excelsa }\end{array}$ & $\begin{array}{l}\text { Entandrophragma } \\
\text { Cylindricum }\end{array}$ & $\begin{array}{l}\text { Ocotea } \\
\text { michelsonie }\end{array}$ \\
\hline Temperature $(\mathrm{T})$ & ${ }^{\circ} \mathrm{C}$ & 524.28 & 519.67 & 529.11 & 522.67 \\
\hline Pyrolysis time(t) & $\mathrm{H}$ & $3 \mathrm{~h} 30$ & $3 \mathrm{~h} 30$ & $3 \mathrm{~h} 30$ & $3 \mathrm{~h} 30$ \\
\hline Yield & $\%$ & $31.4^{\mathrm{a}}$ & $34.3^{\mathrm{ab}}$ & $33.3^{\mathrm{a}}$ & $36.6^{\mathrm{ab}}$ \\
\hline
\end{tabular}

Whenever the values of the characteristics of the biochars carry at least two different letters, there is significant difference between the averages.

All the biochars were obtained between 500 and $550{ }^{\circ} \mathrm{C}$ after $3 \mathrm{~h} 30$ minutes (Table 1). This was in order to optimize biochar's porosity and ash content. Temperatures were moderately high due to the thermal insulation of the furnace and the steady maintenance of the fire during the process. The process was thus a fast pyrolysis (Tripathiet al., 2016; Lee et al., 2017). The yield values were $31.4 \%$ for EMB, 34.3\% for MEB, 33.3\% for ECB and 36.6\% for OMB. The yield of EMB was significantly different from that of MEB and OMB and Ocotea michelsonie had the highest yield. The differences could be due to difference in density between the biochars (Boris et al., 2018). Also, higher yield for OMB could be due to a higher lignin content in Ocotea michelsonie wood as compared to others (Maga, 1986; Brewer et al., 2014). The yields were similar to those found by Niazi et al. (2017) for two biochars produced at $300^{\circ} \mathrm{C}$ and $700{ }^{\circ} \mathrm{C}$ but far below that reported by Lau et al. (2017). This was due to pyrolysis temperature which caused the loss of condensable materials and led to high ash content (Zama et al., 2017). Brewer et al. (2014) equally reported decrease in biochar with increasing biochar's production temperature. $\mathrm{OH}$ et al.(2012) argued that decrease in biochar yield with increasing pyrolysis temperature might be due to the destruction of chemical constituents, such as cellulose and hemicelluloses, included in the biomass.

\subsection{Characteristics of biochars}

Results of all the analysed physical and chemical parameters are summarized in Table 2 
Table 2: Physical and chemical properties of biochar from some selected wood species

\begin{tabular}{|c|c|c|c|c|c|}
\hline Parameter & Unit & $\begin{array}{c}\text { Eucalyptus Maideni } \\
\text { Biochar(EMB) }\end{array}$ & $\begin{array}{l}\text { Milicia excelsa } \\
\text { Biochar(MEB) }\end{array}$ & $\begin{array}{c}\text { Entandrophragma } \\
\text { cylindricum } \\
\text { Biochar(ECB) }\end{array}$ & $\begin{array}{c}\text { Ocotea } \\
\text { Michelsonie } \\
\text { Biochar(OMB) }\end{array}$ \\
\hline & \multicolumn{5}{|c|}{ Physical properties } \\
\hline Bulk density $\left(\rho_{\mathrm{a}}\right)$ & g.cm ${ }^{-3}$ & $0.19^{\mathrm{a}}$ & $0.18^{\mathrm{a}}$ & $0.16^{\mathrm{a}}$ & $0.17^{\mathrm{a}}$ \\
\hline Particle density $\left(\rho_{\mathrm{s}}\right)$ & g. $\mathrm{cm}^{-3}$ & $0.32^{\mathrm{a}}$ & $0.50^{\mathrm{c}}$ & $0.39^{\mathrm{ab}}$ & $0.47^{\mathrm{bc}}$ \\
\hline Porosity $(\Theta)$ & $\%$ & $94^{\mathrm{a}}$ & $93^{\mathrm{a}}$ & $92^{\mathrm{a}}$ & $92^{\mathrm{a}}$ \\
\hline $\begin{array}{l}\text { uniformity } \\
\text { Coefficient (UC) }\end{array}$ & & $3.2^{\mathrm{a}}$ & $3.9^{\mathrm{b}}$ & $4.3^{\mathrm{c}}$ & $3.6^{\mathrm{b}}$ \\
\hline Water content $(\mathrm{W})$ & $\%$ & $6^{\mathrm{b}}$ & $8^{\mathrm{c}}$ & $7^{b c}$ & $4^{\mathrm{a}}$ \\
\hline & \multicolumn{5}{|c|}{ Chemical properties } \\
\hline $\mathrm{pH}$ & & $7.3^{\mathrm{b}}$ & $7.40^{\mathrm{b}}$ & $7.70^{\mathrm{a}}$ & $7.90^{\mathrm{a}}$ \\
\hline $\begin{array}{l}\text { Electrical } \\
\text { Conductivity (EC) }\end{array}$ & & $0,04^{\mathrm{a}}$ & $0,01^{\mathrm{b}}$ & $0,07^{\mathrm{a}}$ & $0,14^{\mathrm{c}}$ \\
\hline Ash content & $\%$ & $9.40^{\mathrm{a}}$ & $12.30^{\mathrm{b}}$ & $16.8^{\mathrm{c}}$ & $18.40^{\mathrm{d}}$ \\
\hline $\begin{array}{l}\text { Total Carbon } \\
\left(\mathrm{C}_{\mathrm{Tot}}\right)\end{array}$ & $\%$ & $54.30^{\mathrm{a}}$ & $55.85^{b}$ & $54.80^{\mathrm{ab}}$ & $55.60^{\mathrm{b}}$ \\
\hline $\begin{array}{l}\text { Organic Carbon } \\
\left(\mathrm{C}_{\text {org }}\right)\end{array}$ & $\%$ & $39.65^{\mathrm{a}}$ & $39.10^{\mathrm{a}}$ & $40.03^{\mathrm{a}}$ & $32.72^{c}$ \\
\hline $\begin{array}{l}\text { Total Nitrogen } \\
\text { (TN) }\end{array}$ & $\mathrm{mg} / \mathrm{kg}$ & 3786.6 & 946.6 & 1437 & 3254 \\
\hline Chloride & $\mathrm{mg} / \mathrm{kg}$ & $792^{a}$ & $643^{\mathrm{a}}$ & $703^{b}$ & $589^{\mathrm{c}}$ \\
\hline Total Phosphorus & $\mathrm{mg} / \mathrm{kg}$ & $250.7^{\mathrm{a}}$ & $280.3^{b}$ & $260.9^{c}$ & $230.1^{\mathrm{d}}$ \\
\hline Ammonium & $\mathrm{mg} / \mathrm{kg}$ & $11.08^{\mathrm{a}}$ & $5.50^{\mathrm{b}}$ & $11.08^{\mathrm{c}}$ & $12.94^{\mathrm{d}}$ \\
\hline Nitrate & $\mathrm{mg} / \mathrm{kg}$ & $12.4^{\mathrm{a}}$ & $9.92^{b}$ & $2.48^{\mathrm{c}}$ & $7.44^{\mathrm{d}}$ \\
\hline \multirow[t]{2}{*}{ Nitrite } & $\mathrm{mg} / \mathrm{kg}$ & $9.20^{\mathrm{a}}$ & $7.41^{\mathrm{b}}$ & $1.84^{\mathrm{c}}$ & $5.52^{d}$ \\
\hline & \multicolumn{5}{|c|}{ Heavy metals } \\
\hline Aluminium & $\mathrm{mg} / \mathrm{kg}$ & $<0,01$ & $<0,01$ & $<0,01$ & $<0,01$ \\
\hline Arsenic & $\mathrm{mg} / \mathrm{kg}$ & $<0,01$ & $<0,01$ & $<0,01$ & $<0,01$ \\
\hline Copper & $\mathrm{mg} / \mathrm{kg}$ & $<0,01$ & $<0,01$ & $<0,01$ & $<0,01$ \\
\hline Iron & $\mathrm{mg} / \mathrm{kg}$ & $642^{\mathrm{a}}$ & $504^{b}$ & $680^{c}$ & $594^{\mathrm{d}}$ \\
\hline Nickel & $\mathrm{mg} / \mathrm{kg}$ & $<0,025$ & $<0,025$ & $<0,025$ & $<0,025$ \\
\hline Lead & $\mathrm{mg} / \mathrm{kg}$ & $<0,01$ & $<0,01$ & $<0,01$ & $<0,01$ \\
\hline \multirow[t]{2}{*}{ Zinc } & $\mathrm{mg} / \mathrm{kg}$ & $3,21^{\mathrm{a}}$ & $4,32^{\mathrm{a}}$ & $4,41^{\mathrm{b}}$ & $2,70^{c}$ \\
\hline & \multicolumn{5}{|c|}{ Exchangeable Bases } \\
\hline Potassium & $\mathrm{Cmol} / \mathrm{kg}$ & $2,99^{\mathrm{a}}$ & $6,860^{\mathrm{b}}$ & $7,50 a^{b}$ & $3,80^{\mathrm{a}}$ \\
\hline Calcium & $\mathrm{Cmol} / \mathrm{kg}$ & $81,03^{\mathrm{a}}$ & $81,79^{b}$ & $96,41^{\mathrm{c}}$ & $108,87^{d}$ \\
\hline Magnésium & $\mathrm{Cmol} / \mathrm{kg}$ & $2,52^{\mathrm{a}}$ & $2,70^{\mathrm{b}}$ & $1,52^{\mathrm{c}}$ & $1,80^{\mathrm{d}}$ \\
\hline Sodium & $\mathrm{Cmol} / \mathrm{kg}$ & $0,52^{\mathrm{a}}$ & $0,48^{\mathrm{a}}$ & $0,44^{\text {ab }}$ & $0,56^{\mathrm{b}}$ \\
\hline
\end{tabular}

Whenever the values of the characteristics of the biochars carry at least two different letters, there is significant difference between the averages.

\subsubsection{Physical properties}

Bulk density ranged from 0.16 to 0.19 g.cm $\mathrm{cm}^{-3}$ with EMB having the highest value without any significant difference, while particle density ranged from 0.39 to $0.50 \mathrm{~g} . \mathrm{cm}^{-3}$ with MEB having the highest value, significantly greater than those of EMB and ECB (Table 2). These values are lower than those reported in the literature by (Niazi et al., 2017) and (Boris et al., 2018) and seemed to have been influenced by pyrolysis temperature and the type of wood material (Kaudal et al., 2015).

All the biochars had very high porosities ranging between 92 and $94 \%$ with EMB having the highest value. No significant difference in porosity was observed between biochars $(p>0.05)$. High porosity was due to high temperature reached during the pyrolysis of biochars which led to the release of volatile matter and thus, creating more pores [Niazi et al., 2017; Kaudal et al., 2015; NF EN 933-8, 2012). The high porosities suggest increased capacity of biochar to absorb certain contaminants from water implying that if the biochars obtained in this study are used as filter media, they will have better capacity to hold water in macropores as well as better capacity to grow biofilm in the pores, which is important for water treatment (Tomczyk et al., 2020).

The uniformity coefficient of MEB (4.3\%) was greater than 4 suggesting that this biochar had a well-spread particle size without the predominance of a particular fraction. Those of ECB, EMB and OMB were 3.9\%, 3.2\% and 3.6\% respectively Their grain sizes were poorly graded given that all the UC values were below 4 (Dalahmeh, 2016). These values are similar to those found by 
(Boris et al., 2018). Water content also differed from one biochar to the other attributed to wood species (8\% for MEB, 7\% for $\mathrm{ECB}, 6 \%$ for $\mathrm{EMB}$ and $4 \%$ for $\mathrm{OMB})$.

\subsubsection{Chemical properties}

The ash contents (9.4\% for MEB, $12.3 \%$ for ECB, $16.8 \%$ for EMB and $18.40 \%$ for OMB) significantly differ from one biochar to the other and were very low compared to others encountered in literature (Yargicoglu et al., 2015; Zama $t$ al., 2017). This proves a good characteristic of these biochars to purify water. These results are in accordance with the observations of Ronsse et al.(2013) and Li et al.(2017) who found that wood-based biochar particularly has high surface area and lower ash compared to other biochars, which might be due to the higher proportions of lignin, cellulose, and hemicellulose in the former than the latter.

$\mathrm{pH}$ ranged from 7.3 to 7.9 with OMB having the highest value and the biochars ranged from neutral to weakly alkaline without any significant difference. The values were similar to those of biochars produced at high temperatures reported by Rehrah et al.(2017). $\mathrm{pH}$ values obtained in this study were surely dependent on pyrolysis temperature. This is because biochar $\mathrm{pH}$ generally increases with pyrolysis temperature as a result of the loss volatile organic compounds and an increase in the basic cations in the biochar (NF EN 933-8, 2012; Mohan et al., 2014). The obtained biochars are thus suitable for water treatment as high $\mathrm{pH}$ promotes the deprotonation of functional groups on the surface of biochar. This creates negative charges that increase the attraction between the absorbent surface and adsorbing cations resulting in high adsorption capacity for some metals present in water (Sabry et al., 2019).

The values of electrical conductivities (0.07 for MEB, 0.01 for ECB, 0.04 for EMB and 0.14 for OMB) reflect the amounts of salts dissolved in the biochars. Electrical conductivities significantly differ between biochars and the highest value obtained for OMB could be attributed to the large amount of ash it contained (Dalahmeh, 2016; Boris et al., 2018). Total carbon $\left(\mathrm{C}_{\mathrm{Tot}}\right)$ content of all biochars was greater than $50 \%$. The large percentage of carbon was attributed to pyrolysis temperature due to organic matter (cellulose, lignin) decomposition that led to the formation of turbostratic and graphite carbons (NF EN 933-8, 2012). Organic carbon $\left(\mathrm{C}_{\mathrm{org}}\right)$ ranged between 32.72 and $40.03 \%$ with ECB recording the highest value. The values were all below $50 \%$ suggesting the decomposition of organic matter due to pyrolysis temperature. However, these values are all above that obtained in Eucalyptus back under similar conditions by (Boris et al., 2018).

High total nitrogen $(946.6-3786.6 \mathrm{mg} / \mathrm{kg}$ ), Chloride $(589-792 \mathrm{mg} / \mathrm{kg})$, nitrate $(2.48-12.40 \mathrm{mg} / \mathrm{kg})$, ammonium $(5.50-12.94$ $\mathrm{mg} / \mathrm{kg}$ ), and nitrite (1.84-9.20 mg/kg) were also obtained in the biochars with EMB recording highest values (Table 2). High total nitrogen found in this study could be due to the fact that all nitrogen containing compounds were not completely carbonized. These results are in disagreement with the prediction of (Tomczyk et al., 2020) who stipulated that nitrogen is generally lost during pyrolysis, resulting to less than $6 \%$ nitrogen in biochars. Most heavy metals were below environmental threshold values except iron $(504-680 \mathrm{mg} / \mathrm{kg}$ ) with ECB having the highest value.

The presence of exchangeable bases in the biochars such as potassium $(2.99 \mathrm{Cmol} / \mathrm{kg}$ for EMB, $6.860 \mathrm{Cmol} / \mathrm{kg}$ for MEB, 7.5 $\mathrm{Cmol} / \mathrm{kg}$ for $\mathrm{ECB}$, and 3.8/kg for OMB), Calcium $(81.79 \mathrm{Cmol} / \mathrm{kg}$ for EMB, $81.71 \mathrm{Cmol} / \mathrm{kg}$ for MEB, $96.41 \mathrm{Cmol} / \mathrm{kg}$ for ECB, and $108.41 \mathrm{Cmol} / / \mathrm{kg}$ for OMB), Magnesium $(2.52 \mathrm{Cmol} / \mathrm{kg}$ for EMB, $2.7 \mathrm{Cmol} / \mathrm{kg}$ for MEB, $1.52 \mathrm{Cmol} / \mathrm{kg}$ for ECB, and 1.8 $\mathrm{Cmol} / \mathrm{kg}$ for OMB), Sodium $(0.58 \mathrm{Cmol} / \mathrm{kg}$ for EMB, $0.44 \mathrm{Cmol} / \mathrm{kg}$ for MEB, $0.48 \mathrm{Cmol} / \mathrm{kg}$ for ECB, and $0.56 \mathrm{Cmol} / \mathrm{kg}$ for $\mathrm{OMB})$ could be explained by the percentage of ash contained in the biochars. This suggests that in contact with water containing heavy metals these bases will be exchanged for the latter, thus increasing biochars capacities in purifying the water. However, except calcium, the concentrations of the other bases were low due to the fact that they are temperature dependent, thus decreasing with increasing temperature (Mukherjee et al., 2011).

\section{Conclusion}

This research valorizes biomass generated from wood mill in the city of Goma which for the production of biochar which may serve as a potential water purifier thus, mitigating environmental pollution as well as providing sustainable portable water supply to households in Goma. Four wood species (Eucalyptus maideni, Milicia excelsa, Entandrophragma cylindricum and Ocotea michelsonie) are commonly used in Goma. The yield values were 34.3\% for MEB, 33.3\% for ECB, 31.4\% for EMB and 36.6\% for OMB. The values were slightly different from each other with Ocotea michelsonie having the highest yield. The high porosity of the biochars gives them a good capacity to absorb contaminants from water. In addition, the ability to remove pollutants in water by biochar from wood could be attributed to its characteristics such as high porosity, large area, $\mathrm{pH}$, high ash content, and alkalinity. Results obtained may help to determine the appropriate conditions to have a good efficiency of removing contaminants from water using biochars obtained from wood sawdust in the city of Goma.

\section{Acknowledgements}

Our thanks go first to the initiators of the cooperation between Great Lakes Free University/Goma/DRC and the University of Dschang/Cameroon. It is thanks to this agreement that this research was carried out. Immense thanks to the laboratory teams at the Great Lakes Free University/Goma/DRC, the University of Dschang/Cameroon and the Institute of Agricultural Sciences of Burundi, for their availability in carrying out the various analyses for this study. 


\section{References}

Biosengazeh, N. F., Mofor, N. A., Tamungang, N. E. B., Mvondo-Ze, A. D. 2020. Assessment of ground water quality in Baba I Village, North-West Cameroon. Journal of Geoscience and Environment Protection, vol. 8, pp. 87-104. DOI: 10.4236/gep.2020.84007

Boris, M. D. K., Suzane, E.A., Alison, O .M. 2018. Quality of biochars made from eucalyptus tree bark and corncob using a pilot-scale retort kiln. Waste Biomass Valorization, Vol. 9, pp. 899-909. https://doi.org/10.1007/s12649-017-9884-2

Bremner, J. M. 1965. Methods of Soil Analysis: Part 2 Chemical and Microbiological Properties, 9.2. American Society of Agronomy, Inc, Agronomy monographs,

Brewer, C. E., Chuang, V. J., Masiello, C. A. et al., New approaches to measuring biochar density and porosity. Biomass and Bioenergy, pp 1-10.

Centre d'Expertise en Analyse Environnementale du Québec (CEAEQ). 2015. Détermination de la conductivité : méthode électrométrique, MA. 115 - Cond. 1.1, rév. 1. Ministère du Développement durable, de l'Environnement et de la Lutte les changements climatiques.

Dalahmeh, S. S. 2016. Capacity of biochar filters for wastewater treatment in onsite systems - Technical Report. SLU report, SLU - Swedish University of Agricultural Sciences. Uppsala, Sweden.

Downie, A., Krosky, A., Munroe, P. 2009. Physical Properties of Biochar. In Biochar for Environmental Management Science and Technology. Lehmann, J., Joseph, S., Eds.; Earthscan: London, UK.

EBC. 2013. Guidelines. The European Biochar Certificate, pp 16.

Enaime, G., Baçaoui A, Yaacoubi, A., Lübken, M. 2020. Biochar for Wastewater Treatment-Conversion Technologies and Applications: Review. Applied Sciences, Vol. 10, pp 1-29.

Gwenzi, W. 2018. Biochar-Based Filters: A Frugal Technology for Drinking Water Supply in Developing Countries? Africa \& Science, pp. 16.

Kaudal, B.B., Chen, D., Madhavan, D. B., Downie, A., Weatherley, A. 2015. Pyrolysis ofurban waste streams: Their potential use as horticultural media. Journal of Analytical and Applied Pyrolysis, Vol. 112, pp. 105-112.

Laine, J., S. Simoni and R. Calles. 1991. Preparation of activated carbon from coconut shell in a small scale concurrent flow rotary kiln. Chemical Engineering Communications, vol 99, pp 15-23.

Lau, A.Y.T., Tsang, D.C.W., Graham, N., Ok, Y., Yang, X., Li, X. 2017. Surface-modified biochar in a bioretention system for Escherichia coli removal from stormwater. Chemosphere, Vol.169, pp. 89-98.

Lee, J., Yang, X., Cho, S. H. 2017. Pyrolysis process of agricultural waste using $\mathrm{CO}_{2}$ for waste management, energy recovery, and biochar fabrication. Applied Energy, vol. 185, pp. 214-222.

Lehmann, J. 2009. Terra preta Nova - where to from here? In: Woods, Amazonian Dark Earths. WimSombroek's Vision. Springer, pp. 473-48.

Lele, N. B. 2016. Potentiel d'amélioration de la fertilité des sols sableux et acides de Kinshasa(RDC) par usage du charbon des bois (Biochar), de la biomasse végétale et des engrais minéraux. Thèse de Doctorat, ERAIFT, 2016. pp. 243.

Li, H., Dong, X., Da Silva, E. B. 2017. Mechanisms of metal sorption by biochars: biochar characteristics and modifications. Chemosphere, Vol. 178, pp. 466-478.

Lim, T. J., Spokas, K. A., Feyereisen, G. W., Weis, R., Koskinen, W. C. 2017. Influence of Biochar Particle Size and Shape on Soil Hydraulic Properties. Journal of Environmental Science and Engineering Technology, Vol. 5, pp 8-15.

Lumnwi, M., Fantong, W. Y., Ayonghe, S. N. 2018. Challenges of potable water supply management in Bafut Sub-Division, North West Region of Cameroon. International Journal of Research - Granthaalayah, Vol. 6, pp. 256-273.

Maga, J. A. 1986. Polycyclic aromatic hydrocarbon (PAH) composition of mesquite (Prosopis fuliflora) smoke and grilled beef. Journal of Agricultural and Food Chemistry, Vol 34, pp. 249-251.

Mohan, D., Kumar, H., Sarswat, A., et al. 2014. Cadmium and lead remediation using magnetic oak wood and oakbark fast pyrolysis bio-chars. Chemical Engineering Journal, Vol, 236, pp. 513-528.

Mukherjee, A., Zimmerman, A.R., Harris, W. 2011. Surface chemistry variations among a series of laboratory-produced biochars. Geoderma, Vol. 163, pp. 247-255

Naeem, M. A., Khalid, M., Arshad, M., Ahmad, R. 2014. Yield and nutrient composition of biochar produced from different feedstocks at varying pyrolytic temperatures. Pakistan Journal of Agricultural Sciences, Vol. 51, pp 75-82.

National Renewable Energy Laboratory. 2008. Determination of Ash in Biomass. Laboratory Analytical Procedure (LAP). Technical Report. A national laboratory of the U.S. Department of Energy, pp 1-8.

Nchofua, F. B., Njoyim, E. B., Mofor, N. A., Mvodo-Ze, A. D. 2020. Analysis and water quality control of alternative sources in Bangolan, Northwest Cameroon, Hindawi Journal of Chemistry, Vol. 2020, pp. 13. https://doi.org/10.1155/2020/5480762

NF EN 933-8. 2012. Essais pour déterminer les caractéristiques géométriques des granulats-partie 1: détermination de la granularité-Analyse Granulométrique par tamisage . AFNOR, Paris, France.

NF P 94-054. 1991. Sols : Reconnaissance et Essais-Détermination de la masse volumique des particules solides des sols-Méthode du pycnomètre à eau, AFNOR, Paris, France. 
NF X 31-503,1992. "Qualité des sols, Méthodes physiques, Mesure de la masse volumique apparente, Méthode au sable" AFNOR, Paris, France.

Niazi, N. K., Bibi, I., Shahid, M., Ok, Y. S., Burton, E. D., Wang, H., Shaheen, S. M., Rinklebe, J., Lüttge, A. 2017. Arsenic removal by perilla leaf biochar in aqueous solutions and groundwater: An integrated spectroscopic and microscopic examination. Environmental Pollution, pp. 1-11. https://doi.org/10.1016/j.envpol.2017.09.051

Niwagaba, C. B., Dinno, P., Wamala, I., Dalahmeh, S. S., Lalander, C., Jönsson, H. 2014. Experiences on the implementation of a pilot grey water treatment and reuse based system at a household in the slum of Kyebando-Kisalosalo, Kampala. Journal of Water Reuse Desalination, Vol 4, pp. 294-307. DOI: 10.2166/wrd.2014.016

OH, T., Choi, B., Shinogi, Y., Chikushi, J. 2012. Characterization of biochar derived from three types of biomass. Journal of the Faculty of Agriculture Kyushu University, Vol. 57, pp 61-66. DOI: 10.5109/22049

Pauwels, J., Ranst, E,V., Verloo, M., Mvondo-Ze, A. D. 1992. Méthodes d'analyses de sols et de plantes. Manuel de Laboratoire de Pédologie - équipement et gestion des stocks de verrerie et de produits chimiques, Bruxelles, Belgique,.

Peltier, R., Bisiaux, F., Dubiez, E., Marien, J. N., Muliele, J. C., Proces, P., Vermeulen. C. 2010. De la culture itinérante sur brûlis aux jachères enrichies productrices de charbon de bois, en Rep. Dem. Congo ISDA 2010, Jun 2010, Montpellier, France. CiradInra-SupAgro, hal-00512274.

Perez-Mercado, L. F., Lalande, C., Berger, C., Dalahmeh, S. S. 2018. Potential of biochar filters for onsite wastewater treatment: effects of biochar type, physical properties and operating conditions. Water, Vol 10, pp.1835. https://doi.org/10.3390/w10121835

Rajkovich, S., Enders, A., Hanley, K., Hyland, C., Zimmerman, A.R., Lehmann, J. 2011. Corngrowth and nitrogen nutrition after additions of biochars with varying properties to a temperate soil. Biology an. Fertily of Soils, Vol 48, pp. 271-284. https://doi.org/10.1007/s00374-011-0624-7

Rasheed, A., Sana, S., Kashif, S., Umer, Z., Khatoon, M. 2017. To evaluate the efficiency of char and biochar for waste water treatment. Journal of Waste Recycling, Vol.2, pp 1-6

RDC. 2018. Plus importante épidémie de choléra de ces 20 dernières années. Available on https://www.msf-azg.be/.../rdc-plusimportante-épidémie-de-choléra-de-ces-20 dernières années. Visited on 14 April 2020

Rehrah D., Bansode R.R., Hassan O., Ahmedna M. 2016. Physicochemical characterization of biochars from solid municipal waste for use in soil amendment. Journal of Analytical and Applied Pyrolysis, Vol. 118, pp. 42-53. https://doi.org/10.1016/j.jaap.2015.12.022

Rodier J, Bernard L., Nicole M. et al. 2009. Analyse de l'eau. $9^{\mathrm{e}}$ édition. Dunod, Paris, France.

Ronsse F., van Hecke S., Dickinson D., Prins W. 2013. Production and characterization of slow pyrolysis biochar: influence of feedstock type and pyrolysis conditions. Global Change Biology Bioenergy, Vol. 5, pp. 104-115. https://doi.org/10.1111/gcbb.12018

Sabry, M. S., Niazi, N. K., Noha, E. E. H., Bibi, I., Wang, H., Tsang, D. C. W., On, Y. S., Bolan, N., Rinklebe, J. 2019. Woodbased biochar for the removal of potentially toxic elements in water and wastewater: a critical review. International Material Reviews, Vol. 64, No 4, pp. 216-247. https://doi.org/10.1080/09506608.2018.1473096

Schure, J., Pinta, F., Cerutti, P. O., Kasereka-Muvatsi, L. 2019. Efficiency of charcoal production in Sub-Saharan Africa: Solutions beyond the kiln. Bois et Forêts des Tropiques, Vol, 340, pp. 57-70. https://doi.org/10.19182/bft2019.340.a31691

Tomczyk, A., Sokołowska, Z., Boguta, P. 2020. Biochar physicochemical properties: pyrolysis temperature and feedstock kind effects. Reviews in Environmental Science and Biotechnology, Vol. No. 19, pp. 191-215.

Tripathi, M., Sahu, J. N., Ganesan, P. 2016. Effect of process parameters on production of biochar from biomass waste through pyrolysis: a review. Renewable and Sustainable Energy Reviews, Vol. 55, pp. 467-481. https://doi.org/10.1016/j.rser.2015.10.122

UNICEF and WHO. 2015. 2015 Update and MDG Assessment Report: Progress on Sanitation and Drinking Water. Geneva: World Health Organization and United Nations International Children Emergency Fund.

United Nations (UN). 2015. Transforming Our World: The 2030 Agenda for Sustainable Development, United Nations (UN), New York, NY, USA.

Wu, W., M. Yang, Q. Feng, K. Mcgrouther, H. Wang, H. Lu and Y. Chen. 2012. Chemical characterization of rica straw-derived biochar for soil amendment. Biomass Bioenergy, Vol. 47, pp 268-276.

Yargicoglu, E. N., Sadasivam, B. Y., Reddy, K. R. 2015. Physical and chemical characterization of waste wood derived biochars. Waste Management, Vol 36, pp. 256-268. https://doi.org/10.1016/j.wasman.2014.10.029

Ye, S., Zeng, G., Wu, H., Liang, J., Zhang, C., Dai, J., Xiong, W., Song, B., Wu, S., Yu, J. 2019. The effects of activated biochar addition on remediation efficiency of co-composting with contaminated wetland soil. Resources Conservation and. Recycling, Vol. 140, pp. 278-285. https://doi.org/10.1016/j.resconrec.2018.10.004

Zama, E. F., Zhu, Y. G., Reid, B. J. 2017. The role of biochar properties in influencing the sorption and desorption of $\mathrm{Pb}(\mathrm{II})$, $\mathrm{Cd}(\mathrm{II})$ and $\mathrm{As}(\mathrm{III})$ in aqueous solution. Journal of Cleaner Production, Vol. 148, pp. 127-136. https://doi.org/10.1016/j.jclepro.2017.01.125 


\section{Biographical notes}

Amboko Benjamin Muhiwa has a BSc in Building and Public Works in Kinshasa - DRC; MSc in Rural Engineering in Brazil and currently doing a Doctorate in Water Management at the University of Dschang in Cameroon. He is a Researcher/Lecturer at the Free University of Great Lakes countries, Goma, DRC

Mathias Fru Fonteh is a Professor of water resources management at the University of Dschang in Cameroon. He is currently the Director of The College of Technology, at The University of Bamenda in Cameroon. He has taught courses like; irrigation and drainage, integrated water resources management, water table management, emergency water supply, water security \& climate resilient development and agricultural hydraulics. He is an expert in sustainable water resources management for socioeconomic development in a changing climate based on the principles of integrated water resources management.

Estella Buleng Tamungang Njoyim is an Associate Professor of Environmental Chemistry at The University of Bamenda in Cameroon and a Researcher at the University of Dschang. She is currently the Head of Department of Chemistry, at the Higher Teacher Training College of The University of Bamenda. She has taught courses like Environmental Impact Assessment, Various aspects of Environmental Chemistry, Teaching and Research methods in chemistry, Analytical chemistry as well as General concepts in chemistry. She is an expert in Water and soil pollution assessment and remediation as well as Environmental impact assessment.

François N. Gapgue is a holder a BSc in Civil Engineering in USSR, Master of Engineering in USSR, an a PhD in Engineering Sciences in UKRAINE. He is an Associate Professor of Engineering in the University of Dschang, Cameroon. 